\title{
Craftsmanship and the Guilds in the Late Middle Ages: The Testimony of Des Teufels Netz and of the Mendel Housebooks
}

\author{
Albrecht Classen \\ The University of Arizona, Tucson, Arizona, USA
}

\begin{abstract}
Placing the anonymous didactic poem Des Teufels Netz next to the Mendelschen Zwölfbrüderstiftung zu Nürnberg, we gain most valuable access to the world of craftsmen in the late Middle Ages. Even though the author of the first text pursues mostly ethical and moral concerns, formulating many specific comments about people's wrongdoing, his narrative proves to be almost as informative about craftsmen as the Mendel Housebook (short title). The latter mostly consists of a very large number of illustrations of old craftsmen working in their shops, which sheds important light on the tools available, the work methods, and the impressive differentiation and sophistication amongst the craftsmen. The Housebook was continued until the early nineteenth century, whereas Des Teufels Netz was mostly forgotten and did not experience a significant reception. Both works complement each other well and allow us to gain an excellent insight into the world of craftsmen.
\end{abstract}

Keywords: Des Teufels Netz, Mendelschen Zwölfbrüderstiftung zu Nürnberg, medieval craftsmen, didactic and memorial literature

Although we tend to focus, when studying medieval society, on knighthood, the clergy, and the peasants as the three dominant estates throughout the Middle Ages, nothing would be fully explainable or understandable without a close examination of the rising class of craftsmen and also craftswomen who mostly lived in urban centers since the early Middle Ages and gained a significant, almost central role by the late Middle Ages. Similarly, as important as the church/monastery and the court were as the central locations of medieval culture and power, there is plenty of evidence by now confirming the increasingly significant role played by larger and smaller cities sprouting all over Europe since the twelfth and thirteenth centuries. ${ }^{1}$ Many different people lived in cities, as is the case today. But medieval cities were strongly determined by the craftsmen and the guilds, apart from the merchants.

Of course, we find within the city walls also various monasteries, and the numerous churches were administered by members of the clergy. The city was surrounded by a wall that had to be guarded by soldiers

\footnotetext{
Albrecht Classen, Ph.D., University Distinguished Professor, Dept. of German Studies, University of Arizona

${ }^{1}$ The literature on this topic is huge by now, see, for instance, Norman Pounds, The Medieval City. Greenwood Guides to Historic Events of the Medieval World (Westport, CT, and London: Greenwood Press, 2005); see also the contributions to Urban Space in the Middle Ages and Early Modern Times, ed. Albrecht Classen. Fundamentals of Medieval and Early Modern Culture, 4 (Berlin and New York: Walter de Gruyter, 2009); Städtische Räume im Mittelalter, ed. Susanne Ehrich and Jörg Oberste. Forum Mittelalter, Studien 5 (Regensburg: Verlag Schnell \& Steiner, 2009); City Limits: Perspectives on the Historical European City, ed. Glenn Clark, Judith Owens, and Greg T. Smith (Montreal, Kingston, et al.: McGill-Queen's University Press, 2010); La Gobernanza de la ciudad europea en la edad media, ed. Jesús Ángel, Solórzano Telechea, and Beatriz Arízaga Bolumburu (Logroño: Instituto de Estudios Riojanos, 2011); Städtische Wirtschaft im Mittelalter: Festschrift für Franz Irsigler zum 70. Geburtstag, ed. Rudolf Holbach and Michel Pauly (Cologne, Weimar, and Vienna: Böhlau Verlag, 2011).
} 
and others, and there were money lenders, of course. Moreover, well into the late Middle Ages prostitutes found fairly solid and reliable income, although they did not enjoy a good reputation. Urban centers also included elementary schools, Latin schools, and increasingly also universities, and many of the graduates embarked on careers as notaries, scribes, illuminators and scribes, book keepers, and so forth. ${ }^{2}$

Nevertheless, the craftsmen represented, after all, everywhere the majority of the urban population. Following I will focus on literary and other documents reflecting on craftsmen who operated so prominently in medieval cities. Again, this is a topic which scholars have investigated already numerous times. ${ }^{3}$ To add to the current research, this paper will examine, at least in the first case, heretofore mostly neglected but unique and most illuminating medieval and early modern German documents that will serve exceedingly well to provide excellent insight into the world of craftsmen and which thus will document how much they had gained in public attention and mattered almost equally much as the merchant class, the clergy, and the aristocrats, at least as far as the literary discourse was concerned.

To deal with medieval craftsmanship in general terms might, however, be tantamount to discussing in very general terms such institutions as the medieval Church, or the aristocracy, etc., since the topic is so expansive and relevant for all (!) periods of the Middle Ages. Craftsmen operated in every part of medieval Europe, from Iceland to Spain, from Ireland to Byzantium, and there were as much Arabic and other craftsmen in the neighboring countries as in the Christian world. The questions regarding craftsmen's participation in urban governments, quality control of the products, price and competition regulations, the structure of the education process from apprentice to journeyman to master, the monopoly of the guilds, the technical advancements of and by the craftsmen throughout time, the difference between craftsmen in the countryside versus those in the city, the relationship between the craftsmen and their wives and daughters, the role of Jewish craftsmen especially in the Mediterranean world, in Persia, and in the Ottoman Empire have already found numerous answers in a large body of relevant scholarship. ${ }^{4}$

Countless medieval museum pieces demonstrate vividly the skill and art commanded by those craftsmen, and many written documents produced for the guilds and the city governments provide an extraordinary understanding of the world of craftsmanship. For a number of years beautifully illustrated volumes dedicated to specific crafts in the Middle Ages have been published by the University of Toronto Press. For instance,

\footnotetext{
${ }^{2}$ Research on this topic, as I have already observed, is very rich; see, for instance, Keith D. Killey, Urban Life in the Middle Ages 1000-1450. European Culture and Society (Houndmills, Basingstoke, Hampshire: Palgrave, 2002); id., City and Cosmos: The Medieval World in Urban Form (London: Reaktion Books, 2009); Norman Punds, The Medieval City. Greenwood Guides to Historic Events of the Medieval World (Westport, CT, and London: Greenwood Press, 2005). Cf. also the archeological perspectives on medieval towns provided by John Schofield and Alan Vince, Medieval Towns: The Archaeology of British Towns in Their European Setting. The Archeology of Medieval Europe, 1100-1600 (1994; London and New York: Continuum, 2003), 121-50.

${ }^{3}$ Hans Huth, Künstler und Werkstatt der Spätgotik. 2nd expanded ed. (Darmstadt 1967); Von Schmieden, Würflern und Schreinern: Städtisches Handwerk im Mittelalter. Beiträge des ersten Kolloquiums des Arbeitskreises zur archäologischen Erforschung des mittelalterlichen Handwerks, ed. Ralf Röber. ALManach, 4 (Stuttgart: Theiss, 1999); Wolfgang Metzger, Handel und Handwerk des Mittelalters im Spiegel der Buchmalerei (Graz: Akademische Druck- und Verlagsanstalt, 2002).

${ }^{4}$ See the articles on the various topics relating to craftsmen in Lexikon des Mittelalters, vol. IV (Munich and Zurich: Artemis Verlag, 1989), cols. 1910-19; Steven Epstein, "Guilds and Métiers," Dictionary of the Middle Ages, ed. Joseph R. Strayer, vol. 6 (New York: Charles Scribner's Sons, 1985), 13-20. See also the rich volume, Handwerk und Sachkultur im Spätmittelalter: Internationaler Kongress, Krems an der Donau, 7. bis 10. Oktober 1986, ed. Rolf Sprandel. Veröffentlichungen des Instituts für Mittelalterliche Realienkunde Österreichs, 11 (Vienna: Verlag der Österreichischen Akademie der Wissenschaften, 1988); cf. also Stadt und Handwerk in Mittelalter und früher Neuzeit, ed. Karl Heinrich Kaufhold and Wilfried Reininghaus. Städteforschung; Reihe A; Darstellungen, 54 (Cologne: Böhlau, 2000); Knut Schulz, Handwerk, Zünfte und Gewerbe: Mittelalter und Renaissance. Wissen verbindet (Darmstadt: Wissenschaftliche Buchgesellschaft, 2010).
} 
Matthias Pfaffenbichler introduced the craft of armorers; Nicolas Coldstream worked on masons and sculptors; and Elizabeth Eames focused on English tilers. ${ }^{5}$ The history of craftsmanship can be pursued from many different perspectives, including the training of the young people entering that work field, the social and economic conditions, the supply of raw material and its transformation into finished products, the selling of tools, machines, gadgets, bread, etc., the literary and artistic culture of the craftsmen ("Meistersang"), the craftsmen's political status, and the relationship of the craftsmen to the Church. ${ }^{6}$

The purpose of this paper, however, is to introduce and analyze first a literary source that has not been studied much at all until today and yet deserves much more attention with respect to craftsmanship especially because it is so amazingly rich in its information about many different crafts and how the individuals who occupied those positions as masters behaved, that is, in the author's mind, misbehaved. The second document, a hefty tome with a huge number of illustrations, has been investigated already a number of times especially by German manuscript scholars, but it seems mostly unknown among Anglophone and other researchers and so deserves to be discussed here more thoroughly. The wealth of details about craftsmanship in the Middle Ages and far beyond contained in the second document is breathtaking and deserves great attention by modern scholarship.

At a conference in Göttingen, Germany, in December 2011, a group of philologists discussed the curious phenomenon of "sleeping" and "forgotten" texts from the Middle Ages. ${ }^{7}$ The former group consists of narratives that are extant only in their original manuscript form and have not yet been edited critically; the latter group comprises texts that have already been published sometime in the nineteenth or twentieth century but have never attracted any significant attention by scholars or the wider readership. While the canon of literary texts continues to enjoy widespread popularity in academia and elsewhere, which Nathanael Busch and Björn Reich call "Höhenkammliteratur" (literature situated on the high topographical ridges), ${ }^{8}$ a vast number of presumably "second-ranked" literature, often determined by its religious, medical, geographical, or scientific orientation or character continues to await its rediscovery through new critical readings.

One of those "forgotten" texts proves to be the anonymous didactic verse narrative, Des Teufels Netz from the early fifteenth century, composed somewhere in the vicinity of Constance, southern Germany. The author refers to a Church council, which could entail the Council of Constance (1414-1418) or the Council of Basel (1431-1443), and both this and the specific dialect features provide sufficient evidence to locate this long

\footnotetext{
${ }^{5}$ Nicola Coldstream, Masons and Sculptors. Medieval Craftsmen (Toronto: University of Toronto Press, 1991); Matthias Pfaffenbichler, Armourers. Medieval Craftsmen (Toronto: University of Toronto Press, 1992); Elizabeth Eames, English Tilers. Medieval Craftsmen (Toronto: University of Toronto Press, 1992). This series contains numerous other volumes for specific crafts.

${ }^{6}$ Again, research on these topics goes back a long way; see, for instance, Eduard Otto, Das deutsche Handwerk in seiner kulturgeschichtlichen Entwicklung (Leipzig: Teubner, 1900); Ellinghaus, Geschichte und Wirtschaft der deutschen Handwerks: Wirtschafts-und Organisationsgeschichte des Handwerks. Die Handwerkshochschule, 4.1 (Berlin: Spaeth \& Linde, 1934); Walter Schöler, Handwerk und Zünfte im Mittelalter. Part 1: Das Handwerk. Probiton-Unterrichtsprogramm (Ratingen: Henn, 1965); Handwerk im Mittelalter, ed. Christine Sauer (Darmstadt: Wissenschaftliche Buchgesellschaft, 2012).

7 Vergessene Texte des Mittelalters, ed. Nathanael Busch and Björn Reich (Stuttgart: S. Hirzel, 2014); see my review in Mediaevistik 28 (forthcoming).

${ }^{8}$ See the introduction by Busch and Björn, ed., Vergessene Texte des Mittelalters (see note 7), 9; see also the contributions to Canon and Canon Transgression in Medieval German, ed. Albrecht Classen. Göppinger Arbeiten zur Germanistik, 573 (Göppingen: Kümmerle, 1993); and my "Einleitung" to Literature on the Margin: Perspectives on Trivial Literature from the Middle Ages to the 21st Century, ed. Eva Parra-Membrives and Albrecht Classen. Popular Fiction Studies, 1 (Tübingen: Narr Verlag, 2013), 7-32.
} 
didactic poem in the area of Swabia. ${ }^{9}$ The text has survived in four manuscripts, most complete in ms. A, Karlsruhe, Landesbibliothek, cod. Donaueschingen 113 (dated 1441; 13658 vv.). The time when ms. A was copied down does not require us to associate the poet with the Council of Basel, since the issues then continued to be very similar to those already discussed at the previous Council. ${ }^{10}$ The other manuscripts (B, Neustadt/Aisch, Kirchenbibliothek, MS 30, ca. 1450-1500, 7100 vv.; C, Augsburg, Universitätsbibliothek, cod. Oettingen-Wallerstein 1.3.2o 3, fol. 100r-263v, 1449, 9979 vv; D, Strasbourg, Bibliothèque Nationale et Universitaire, cod. 2333, fols. 1r-99r, 1472, 8900 vv.; E, St. Pölten, Stadtarchiv, H 3, 95 vv, late 15th century) contain only abbreviated versions, but it is difficult if not impossible, to establish any meaningful stemma. ${ }^{11}$

In essence, the author examines the wide range of sins which people commit on a daily basis, and through his satirical style he obviously wants to alert his readers/listeners about their own failings and the dangers for their souls, which the devil would certainly capture and take down to hell as a punishment —of course, a very traditional view long expounded by representatives of the Church since the early Middle Ages. As scholarship on Des Teufels Netz (certainly limited in its scope) has already determined, there are a number of parallels with contemporary plays treating the Judgment Day, then with the rich penitentiary literature, decalogue texts, and confessional tracts. We can also identify, as possible models at least for the description of the many sins, such Middle High German didactic works as Thomasin von Zirclaria's Welsche Gast (The Italian Guest, ca. 1215-1216) and Hugo von Trimberg' Renner (The Runner; early to late thirteenth century). ${ }^{12}$ The closest connections, however, might be with the Buch der Rügen (Book of Chastisements), which was the German translation from 1276-1277 of the Latin tract Sermones nulli parcentis from ca. $1230 .^{13}$

Very similar to the motif of the Dance of Death, ${ }^{14}$ our narrative, Des Teufels Netz, addresses all people of all ages, genders, social status, learning, etc. In fact, already at a brief glance we recognize how much the author had the entire world in mind and hoped to reach the broadest possible audience, alerting them through his didactic text both about the sinfulness almost all people live in, and about the subsequent danger for their souls in the afterlife. ${ }^{15}$ But he also takes a political stance in the larger debates within the Church, rejecting the

\footnotetext{
${ }^{9}$ One example of many would be that he entitles one section "Von den gebewrin" (12802ff.; About the female peasants), and then begins with the term for them "bürinen" (12803). For further details, see the "Schlusswort des Herausgebers," Des Teufels Netz: Satirisch-didaktisches Gedicht aus der ersten Hälfte des fünfzehnten Jahrhunderts, ed. K. A. Barack. Bibliothek des Litterarischen Vereins in Stuttgart, LXX. Rpt. (1863; Amsterdam: Editions Rodopi, 1968), 447-48. He correctly rejects all efforts to recognize in him a Hussite and hence as a speaker of an eastern German dialect.

${ }^{10}$ See the contributions to Reform von Kirche und Reich: zur Zeit der Konzilien von Konstanz (1414-1418) und Basel (1431-1449): Konstanz-Prager historisches Kolloquium (11-17. Oktober 1993), ed. Ivan Hlavácek and Alexander Patschovsky (Constance: Universitätsverlag Konstanz, 1996), and to Die Konzilien von Pisa (1409), Konstanz (1414-1418) und Basel (1431-1449): Institution und Personen, ed. Heribert Müller and Johannes Helmrath. Vorträge und Forschungen, 67 (Ostfildern: Thorbecke, 2007).

${ }^{11}$ For a good description of all manuscripts, plus for an online link to the only available critical edition by Barack, see http://www.handschriftencensus.de/werke/1062 (last accessed on Jan. 20, 2015).

${ }^{12}$ I will return to this literary tradition below in more detail.

${ }^{13}$ Karin Lerchner, "Des Teufels Netz," Die deutsche Literatur des Mittelalters: Verfasserlexikon. 2nd, compl. rev. ed. by Burghart Wachinger et al. Vol. 9, 3-4 (Berlin and New York: Walter de Gruyter, 1995), 723-27. Altogether, there is not much research on this text; see now Georg Hofer, "Wenn der Teufel an den Sünden leidet: Zum satirisch-didaktischen Gedicht 'Des Teufels Netz'," Vergessene Texte des Mittelalters (see note 7), 15-25. While he acknowledges that this verse narrative deserves much more attention, he seems not to have read it altogether, since he never comments on the really interesting aspects in the second half, which this article will illustrate in detail.

${ }^{14}$ Elina Gertsman, The Dance of Death in the Middle Ages: Image, Text, Performance. Studies in the Visual Cultures of the Middle Ages, 3 (Turnhout: Brepols, 2010); she does not, however, treat Des Teufels Netz because her focus rests primarily on art-historical representations.

${ }^{15}$ As to the genre to which this text belongs, falling somewhere between an allegorical poem and a didactic debate poem, see Anke Ehlers, Des Teufels Netz: Untersuchung zum Gattungsproblem. Studien zur Poetik und Geschichte der Literatur, 35 (Stuttgart, Berlin, et al.: Verlag W. Kohlhammer, 1973).
} 
institution of the Church Council (1414-1418) as an expression of arrogance and hubris (96ff.). ${ }^{16}$ Most remarkably, in light of human sinfulness and moral frailty, the poet applies the same religious gauge for all people, although he still observes diligently the numerous social ranks and differentiates between lay people and the clergy. No one, in fact, is spared his criticism, which, in an odd fashion, provides a fascinating equalizing element, although the hermit, who debates with the devil, obviously exempts himself from this universal criticism. The devil's working with his net and ropes, seducing people, is identified as most dangerous, threatening virtually every individual here on earth. Only those who, following St. Anthony's teachings, display proper humbleness would have a chance to avoid the temptations and stay away from a sinful life: "Ain recht diemütig man" (34; a truly humble person).

In essence, the devil and a hermit talk about God and the world, about the seven deadly sins, the 10 commandments, the structure of the Church and its individual officers, including monks and their abbots, nuns and abbesses, then about the various monastic orders, hermits, beguines and beghards, and other clerics, then the vast body of lay society, male and female, from the emperor down to the farmhand and servant. All and everyone prove to be a victim of sinfulness, personal failures, moral and ethical shortcomings, and hence tend to become the devil's prisoners. This is beautifully illustrated on the front page of the Karlsruhe manuscript A, showing us a group of devils all pulling a rope attached to a huge net in which they have caught a wide range of different people, dragging them with them, presumably down to hell. Three grotesquely looking devils seated on a bench placed on the top level of the page (1v) play music instruments, apparently in jubilation about the great catch their fellow devils have made among people from all social classes and groups. ${ }^{17}$

Subsequently the interest turns to the various groups of people within society, beginning with children, and hence their sinfulness, character, ethics, and morality (209ff.). As to be expected for such a didactic writer, the author has many more negative things to report, lamenting about young people's bad behavior and lack of virtues, than about their pleasant and nice personality and individuality. ${ }^{18}$ Next we hear about women in their various life stages (214ff.), ${ }^{19}$ and from there the author turns to the men in individual social classes, beginning with emperors and kings (225ff.).

It is not unusual at all that a late medieval cleric writes such a lengthy treatise with the intention of strongly criticizing the failings of all people who no longer abide by the traditional value system, no longer pay respect to the teachings of the Church, and who disrespect the worldly authorities as well. Of course, as Hubert Hoffmann and then also Georg Hofer have already noted, at the time when Des Teufels Netz was composed, many aspects of the medieval world were already in a disarray, and much of the common power structures were

\footnotetext{
${ }^{16}$ When I refer to an individual section addressing a profession or a social class, I give only the page number where that section begins. When I refer to specific text passages, I will give the full verse count. As to the conciliar movement in the late Middle Ages, see, for instance, the contribution to Die Konzilien von Pisa (1409), Konstanz (1414-1418) und Basel (1431-1449): Institution und Personen, ed. Heribert Müller and Johannes Heimrath. Vorträge und Forschungen, 67 (Ostfildern: Thorbecke, 2007).

${ }^{17} \mathrm{http}: / /$ digital.blb-karlsruhe.de/blbhsl/content/pageview/521501 (last accessed on Jan. 17, 2015).

${ }^{18}$ For the topic of children in medieval society, see Nicholas Orme, Medieval Children (New Haven, CT, and London: Yale University Press, 2001); cf. also the contributions to Childhood in the Middle Ages and the Renaissance: The Results of a Paradigm Shift in the History of Mentality, ed. Albrecht Classen (Berlin and New York: de Gruyter, 2005); for broader perspectives, see Erika Langmuir, Imagining Childhood (New Haven, CT, and London: Yale University Press, 2006). The discussion of childhood in Des Teufels Netz, however, has not yet attracted the attention by medieval scholars working on that age group.

${ }_{19}$ This discourse on women is later resumed when the author has the hermit and the devil reflect on the "edeln hohen wiben" (12067ff.; noble, high ranking women).
} 
deeply challenged, meaning that the canonical ordo-principle was simply no longer in place and in danger of being dismantled altogether, which finds countless echoes in contemporary literature and art works, such as in the highly popular Reformatio Sigismundi from ca. 1439 (first published in 1476). ${ }^{20}$

Irrespective of such moral considerations, however, the thematic structure of this narrative simply means that the author pursues the global ambition of reflecting on all and every social class and group of his time and thus to provide his readers with a broad spectrum of insights into how they operate (or not, according to his ideals), how they are distinguished from each other, and what functions they fulfill. The author pursues a very systematic approach, addressing, first, the emperor, then the king, the duke, count, baron, etc., including the knight and the squire. Subsequently he turns to all the servants working at court, discussing even the lowliest individual. We learn thus much about the entire noble household - in the medieval sense of the word-which involves also the scribes, the hunters, gate keepers, kitchen boys, waiters, and stove heaters.

From there the author makes a sudden move away from the court to the city, beginning with a chapter on the gate keepers (now for the city), the mayor, and the merchants. Only then do we encounter the large number of craftsmen, beginning with the dress maker (289ff.). As should have become clear by now, Des Teufels Netz achieves much more than simply outlining sinful behavior by the various types of people, although this remains the base tenor throughout the entire narrative. As much as the devil and the hermit debate each case from a religious perspective, the ultimate goal proves to be a kind of a mirror of all of human society, from the highest level down to the very bottom. The first section covers the members of the clergy; the second turns to the aristocracy; the third concerns the world of the urban dwellers. Finally, though giving them less room, the author also mentions peasants, their wives, village inn-keepers, gamblers, migrants, and other dubious individuals at the margin of medieval society.

Reflecting on the strongly voiced criticism of the so-called heretics and the general shortcomings of people far and wide-though really separate issues, but in the eyes of the poet one and the same phenomenon-Georg Hofer emphasizes that the central concern in Des Teufels Netz focused on the preservation and partial reconstitution of the traditional values and structures as derived from God. ${ }^{21}$ But as in many other cases of medieval didactic literature, a critical reading can reveal numerous additional perspectives, providing important information about social, economic, and cultural conditions, ${ }^{22}$ about the poet's mental-historical background, ${ }^{23}$ and the dominant value system permeating the entire text. In that regard, we

\footnotetext{
${ }^{20}$ Hubert Hoffmann, Die geistigen Bindungen an Diesseits und Jenseits in der spätmittelalterlichen Didaktik: Vergleichende Untersuchungen zu Gesellschaft, Sittlichkeit und Glauben im "Schachzabelbuch", im "Ring"und in "Des Teufels Netz". Forschungen zur oberrheinischen Landesgeschichte, 22 (Freiburg i. Br.: Albert, 1969), 52; Georg Hofer, "Wenn der Teufel an den Sündern leidet" (see note 13), 15-25; here 21-22. See also Lothar, Graf zu Dohna, Reformatio Sigismundi: Beiträge zum Verständnis einer Reformschrift des fünfzehnten Jahrhunderts. Veröffentlichungen des Max-Planck-Instituts für Geschichte, 4 (Göttingen: Vandenhoeck \& Ruprecht, 1960); Hartmut Boockmann, "Zu den Wirkungen der 'Reform Kaiser Siegmunds," Deutsches Archiv für Erforschung des Mittelalters 35 (1979): 514-41; for a text edition, see Reformatio Sigismundi (Augsburg, Lukas Zeissenmair 1497), with an epilogue by Ursula Altmann (Leipzig: Zentralantiquariat der Deutschen Demokratischen Republik, 1979); see especially the historical-critical edition, Reformation Kaiser Siegmunds, ed. Heinrich Koller. Monumenta Germaniae Historica, 500-1500. Staatsschriften des späteren Mittelalters, VI (Stuttgart: Anton Hiersemann, 1964).

${ }^{21}$ Hofer, "Wenn der Teufel an den Sündern leidet" (see note 13), 24. See also Franz Josef Schweitzer, Tugend und Laster in illustrierten didaktischen Dichtungen des späten Mittelalters. Germanistische Texte und Studien, 41 (Hildesheim and New York: Georg Olms-Weidmann, 1993), 249-325.

${ }^{22}$ See, for instance, Peter Dinzelbacher, Lebenswelten des Mittelalters 1000-1500. Bachmanns Basiswissen, 1 (Badenweiler: Wissenschaftlicher Verlag Bachmann, 2010).

${ }^{23}$ See the contributions to Europäische Mentalitätsgeschicht: Hauptthemen in Einzeldarstellungen, ed. Peter Dinzelbacher. Sec. rev. ed. Kröners Taschenausgabe, 469 (1993; Stuttgart: Alfred Kröner, 2008).
} 
face a unique opportunity with this verse narrative to comprehend what types of crafts were dominant in late medieval towns, how they operated, what kinds of tools they used, what kinds of business they practiced, how they were controlled by the guilds, etc.

Let us first look at the way how this author discusses one of the most generic professions, bakers, who mattered greatly as providers of staple food, that is bread, which was so essential because rice was hardly known in the Middle Ages, while potatoes entered the picture only in the sixteenth century. ${ }^{24}$ Bakers are particularly sinful, as he sees it, because they shamelessly utilize the situation of a famine to increase the price of their products and happily enjoy their profit (9283). Naturally, as still is the case today, the baker works at night or in the very early morning and makes every effort to earn the highest income possible. Since the poor people cannot purchase wheat and bake the bread themselves, they have to rely on the bakers (9291-92), who tend, however, to cheat their customers and use waste products in place of high-quality flour. The author does not actually describe the concrete work conditions and the tools used by bakers, and he does not specify what baked goods he produces, but he presents the entire group of bakers in their often sinful interaction with their customers. This does not come as a surprise because the overarching theme, or the common denominator, of Des Teufels Netz concerns human morality and virtues, or rather the lack thereof. Nevertheless, even here, we recognize, behind the didactic and religious discourse, a clear interest in reflecting on the specific professions by the individual craftsmen; hence here the baker. But the author is, of course, no expert, and can describe the baker's activities and procedures only from the point-of-view of the outsider. In particular, he complains about bakers' common strategy to hide their supplies of wheat in order to increase the price of bread artificially (9327-28). He appeals to the bakers to use only good flour and to serve his customers appropriately, otherwise they would end up, as all other people mentioned in this verse narrative, in the devil's net, and hence in hell.

Subsequently we hear about comparable shortcomings and criminal activities by the millers, the butchers, the fishermen, the haberdashers, the apothecaries and physicians, the barber surgeons, the pimps and go-betweens. Even though we would not call those people "craftsmen" in the narrow sense of the word, they all contributed to the well-being of late-medieval life and sustained their communities by meeting a variety of ordinary needs on a daily basis. But the author directs severe criticism against them all, as he operates, in a way, like a preacher warning all his parishioners about the dangers of sinfulness which could affect everyone at any moment.

To understand better the fundamental approach pursued by the anonymous poet, next I am turning to the chapter on tanners and shoemakers (10586ff.). The hermit wonders whether the devil would like to catch those people working in these two professions in his net as well, which is the standard formula he uses for most chapters to make the devil outline how bad the individual people are and to emphasize that everyone actually belongs into the devil's net. As to be expected, the tanners deserve greatest criticism because they are often rather careless and ruin skins entrusted to them for treatment, without the customers subsequently noticing it because the tanners skillfully hide the problems (10590-95) and make the ruined piece of skin look like new (10600-01). The basic motivation for this action consists of greed, the lust for a financial profit, which emerges

\footnotetext{
${ }^{24}$ Dorothee Farnschläder, Produktion und Verzehr von Brot und Backwaren vom Mittelalter bis zur frühen Neuzeit. Schriftenreihe des Zentralverbandes des Deutschen Bäckerhandwerks, 2 (Bad Honnef: Zentralverband des Deutschen Bäckerhandwerks, 2001); Isabel Koellreuter and Nathalie Unternährer, Brot und Stadt: Bäckerhandwerk und Brotkonsum in Basel vom Mittelalter bis zur Gegenwart (Basel: Schwabe, 2006); Ursula Heinzelmann, Beyond Bratwurst: A History of Food in Germany (London: Reaktion Books, 2014).
} 
as one of the most common reasons for people's wrongdoing, and which is, of course, one of the seven deadly sins. $^{25}$

The author describes in considerable details how the tanner manages to hide the damage and to make the customer believe that the skin is still in good shape, but the emphasis still rests primarily on the religious component, although the narrator does not shrink from making sarcastic remarks, calling the tanner a "from man" (10621; pious man), although he means just the opposite. ${ }^{26}$ Then he turns to the shoemaker, whom he labels the tanner's journeyman (10622), but not in the specific sense of the word since these are two, in very concrete terms, rather distinct crafts despite their co-dependence in their professions. Both craftsmen are, as he implies, similar in their mind-set and are not worried about cheating and deceiving their customers. When working on leather to make a new set of shoes, it often happens that he burns the sole and then covers up that damage, without the peasants, who are identified as his usual customers, noticing it. When a trusting person then puts on the new shoes and believes to have made a good purchase, he quickly realizes the next day already that the shoes are falling apart: "So tuot er morn barfuos gan" (10632; then he will walk barefoot the next morning). Instead of creating water-tight shoes, the shoemaker produces a shoddy product that makes the user experiences water easily entering the shoe, which infuriates him because he realizes that he was cheated by the shoemaker. Or the shoes are built so badly that the user can no longer walk the following day since the feet hurt so badly. Or the leather dries out so terribly that the shoes rapidly shrink and become unusable.

Moreover, the evil shoemaker utilizes poor or bad material in gluing the leather together and so, altogether, emerges as a dishonest man, a deceiver, and a bad craftsman (10634-81). We could identify our religious author as a lay person with regard to the crafts, but he still offers numerous details about how those craftsmen are supposed to work and what material they use. Of course, the ultimate purpose always consists of exposing the sinfulness in all people, to warn them hence about the danger of ending up in hell as punishment, and hence of reprimanding the audience and to change their behavior. Des Teufels Netz yet still proves to be fascinating for the simple reason that it provides detailed information about the various crafts, the materials used, and the ways how the craftsmen try to cheat their customers.

We notice, apart from the strong religious intentions, also deep concerns about the need to maintain quality in the production of all and every item or foodstuff, perhaps as a result of personal experiences with poor bread, bad shoes, or other objects. The narrator points out, for instance, that it happens often that a pilgrim or a poor person purchases shoes and then quickly has to realize that they do not meet the expectations because of their miserable quality. Consequently, the narrator bursts out in loud lamentations and reproaches, calling the shoemakers who are guilty of this sinful behavior "uppig lüt" (10662; arrogant people) who deserve to be condemned. Nevertheless, as the devil admits at the end, if the tanner and the shoemaker confess and repent their wrongdoing, he would have to leave them out of his net and so spare them the misery in hell (10674-76).

The overarching tenor of this long work seems to be rather monotonous, constantly following the same narrative model, presenting ever new groups or classes of people, outlining what is normally expected from

\footnotetext{
${ }^{25}$ Solomon Schimmel, The Seven Deadly Sins: Jewish, Christian, and Classical Reflections on Human Nature (New York: Free Press; Toronto: Maxwell Macmillan Canada; New York: Maxwell Macmillan International, 1992); see also the contributions to The Seven Deadly Sins: From Communities to Individuals, ed. Richard Newhauser. Studies in Medieval and Reformation traditions, 123 (Leiden and Boston: Brill, 2007).

${ }^{26}$ John Haiman Talk is Cheap: Sarcasm, Alienation, and the Evolution of Language (Oxford and New York: Oxford University Press, 1998); see now the contributions to Cornering the Snarket: Sarcasm and Snark in Medieval Literature and Cultures. An Anthology of Essays ed. by Alan Baragona and Elizabeth L. Rambo (forthcoming).
} 
them, and then deconstructing their pretenses, lies, deceptions, and simply their sinfulness. As to the craftsmen, the model consists of describing in considerable detail what kind of work they perform, what products they construct, but then the narrator always indicates how much these craftsmen fail to live up to those ideals and actually try to do everything in their power to make a "fast buck", to use cheap material, to hide damages, to build or make poorly designed or not operable gadgets and objects, which reveals, altogether, their own form of sinfulness. The devil delights in outlining very specifically what each craftsman tends to do as part of his labor and what the sneaky and deceitful approach results in, and this to their customers' great frustration and anger.

The narrator does not present a really discriminating picture of people's shortcomings and moral and religious failures. He proves to be a conservative critic of his society who appeals to all of his parishioners and readers to reform, to repent, and to do penance in order to avoid being trapped by the devil. In fact, Des Teufels Netz basically follows an old tradition of didactic writing, ${ }^{27}$ though the author introduces a considerable spectrum of innovative narrative material to illustrate his laments and complains.

For our purposes it mostly matters only, however, what types of professions he refers to and discusses for his religious intentions. Just as in the previous sections, where the author focused, for instance, on the aristocracy, here he studies many different professions, such as masons and carpenters (10677ff.), blacksmiths and wheel-makers (10770ff.), coppersmiths and boiler makers (10844ff.), goldsmiths (10882ff.), scythe-makers (10927ff.), horseshoe-makers (10965ff.), painters (10997ff.), furriers (11042ff.), and many others. In the middle of all these discussions we also come across a section dedicated to those who speak falsely and pretend to be trustworthy workers (11464ff.).

The conclusion follows the same pattern, warning us about their wrongdoing: "Also tuond si die welt beschissen" (11504; thus they screw the world), but the first section addresses a very different observation, which noticeably varies from his general warnings and condemnations. Even though it is still the devil who is supposed to speak, we can be certain that the author himself makes his voice heard at this moment. God has, as he emphasizes, great mercy for the poor workers. There would be no joy in this world if the workers or craftsmen did not exist. Without the latter, neither knights nor squires, neither monks nor priests could avoid the necessity to do all labor themselves. Everyone would have to go to the fields and work them with their own hands. Irrespective of all pious service by the clergy, at the end there would be only one ultimate need: to get food: "Der andacht ze jungst im brotkorb stat" (11475; at the end devotion finds its haven in the bread basket). God wants to have both clerics and lay people as long as the earth would exist. Consequently, everyone is called upon to carry out his or her tasks and would thus earn the reward to be called God's true servant (11478-79). In other words, the poet does not want to dismiss the craftsmen or other people living in cities as unworthy of God's mercy. As much as the narrator has the devil condemn people for their failures to uphold divine laws and the secular laws, as much does he recognize the craftsmen, for instance, as essential and necessary for the proper functioning of human society.

Thereupon the author examines the lives of sailors (11507ff.), coachmen (11594ff.), sacristans (11825ff.), priests' courtesans (11863ff.), gamblers (11970ff.), all kinds of women in various occupations, peasants,

\footnotetext{
${ }^{27}$ Franz Josef Schweitzer, Tugend und Laster in illustrierten didaktischen Dichtungen des späten Mittelalters. Germanistische Texte und Studien, 41 (Hildesheim and New York: Georg Olms-Weidmann, 1993); see also the contributions to What Nature Does Not Teach: Didactic Literature in the Medieval and Early-Modern Periods, ed. Juanita Feros Ruys. Disputatio, 15 (Turnhout: Brepols, 2008); Cordelia Hess, Social Imagery in Middle Low German: Didactical Literature and Metaphorical Representation (1470-1517). Studies in Medieval and Reformation Traditions, 167 (Leiden and Boston: Brill, 2013).
} 
shepherds, then even prostitutes, robbers, murderers, inn-keepers, and others. Not all types of craftsmen are listed here, but Des Teufels Netz proves to be surprisingly comprehensive and provides a true panopticon of late medieval society, especially within the city. In one chapter he even deals with fools (11661ff.), but here he makes a rather big exception, because for him fools and children are innocent, naive, and simpletons who truly belong to God's own court. They do not diminish God's honor through their silly talk and behavior and are only weak in their minds. In fact, the author requests that people show pity for them and try to teach them how to improve their lives. At the same time he voices harsh criticism of those individuals who falsely assume the mask of fools in order to avoid physical labor and to steal money from other people.

Overall, the author's message proves to be straightforward and strict, warning his audience about all their sinfulness, lack of virtues, personal shortcomings, and advises them sternly not to commit evil deeds. In this regard it does not surprise us that scholarship has hardly paid attention to this lengthy, highly conservative and traditional verse narrative, which might even bore us in its tiresome and repetitive diatribes against all people's evil behavior. But the author lines up countless different craftsmen and workers, discussing their professions, and then, of course, how they cheat people out of their money by selling bad products, making poor gadgets, shoes, clothing, tools, building with bad material, etc.

From a literary-historical perspective there is not much to say about this text because of its endless repetitions and highly traditional, morose comments about every individual here on earth. As Hans Rupprich has already observed, Des Teufels Netz stands in a long tradition of satirical-didactic poems, such as the anonymous fourteenth-century Von dem Hurübel, then the Feigenmuntorden (ca. 1400), Konrad von Ammenhausen's Schachzabelbuch (1337), Hugo von Trimberg's Der Renner (ca. 1300), and Thomasin von Zirclaria's Der Welsche Gast (ca. 1215-1216) ${ }^{28}$ But from a cultural-historical perspective we can conclude that the author provides us with fascinating, highly valuable information regarding many different crafts practiced in a late medieval city.

In fact, we can safely assume that the author lived in an urban environment because he can identify and specify so carefully what the various kinds of craftsmen do professionally and how they allegedly transgress even the basic Christian norms and ethics, turning into sinners during their business with the customers. Interestingly, the narrator does not criticize the craftsmen as such, and he does not have much to say at all about their specific work, which he describes in passing. His focus rests primarily on the ways how the craftsmen use their products or their labor to cheat their customers out of money. In other words, the author primarily views craftsmanship through the lens of a conservative cleric as much as he includes a plethora of comments about what the craftsmen actually do when working on products, on buildings, etc.

While the religious components prove to be rather trite and the result of a deeply pessimistic perspective, the author's readiness to discuss virtually every imaginable social group within both genders, and hence also the plethora of craftsmen, servants, administrators, teachers, pimps and prostitutes, mariners, mid-wives, vineyard workers, and shepherds, makes Des Teufels Netz to a remarkable literary mirror of the social reality of its time.

Insofar as the narrator practically does not leave out any major category, exposes everyone's sinfulness, whether high or low on the social ladder, suggests that he might have been a hermit, or, as Barack had

\footnotetext{
${ }^{28}$ Hans Rupprich, Die deutsche Literatur vom späten Mittelalter bis zum Barock. Part One: Das ausgehende Mittelalter, Humanismus und Renaissance 1370-1520. Geschichte der deutschen Literatur von den Anfängen bis zur Gegenwart, IV. 1 (Munich: C. H. Beck'sche Verlagsbuchhandlung, 1970), 302-05; he also mentions subsequent satirical-didactic poems, such as Josep's Von den sieben Todsünden and the anonymous Die acht Schalkheiten (2nd half of the fifteenth century).
} 
suggested, a beghard who had distanced himself from the ordinary aristocratic or urban community and now comes forth with his harsh criticism directed against everyone. ${ }^{29}$

We know, of course, of numerous other types of written documents, such as obituaries, necrologies, and tax registers reflecting on the many different types of craftsmen and all the other members in the late medieval world. ${ }^{30}$ Des Teufels Netz, however, offers a unique combination of individual generic features, presenting the vast range of all people who make up medieval society from the very top to the very bottom through a literary-religious lens, criticizing all and everyone for not living up to the standards of Christian teachings. As little as Des Teufels Netz offers as a literary work of art, strongly permeated by a conservative moralization, as much does it serve as a valuable source of information about craftsmen and their professions, apart from the many other people among the clergy and the aristocracy.

From here let us turn to another significant document in which we find reflected the world of craftsmen, now even more intensively and vividly than in Des Teufels Netz. This is the Hausbuch der Mendelschen Zwölfbrüderstiftung zu Nürnberg (Housebook of the Mendel Foundation of Twelve Brothers in Nuremberg). The wealthy Nuremberg merchant Konrad Mendel had created, in imitation of similar institutions existing in the Flemish and north German regions run by Beghards and other lay communities, a foundation, or a kind of retirement community for needy old craftsmen in 1388, and since 1425/1426 each individual member was portrayed in the Hausbuch, depicting ever since a growing number of specific craftsmen and their tools. It was continued until 1806 and contains a total of 857 illustrated folios depicting 765 different craftsmen and their tools. $^{31}$

This Zwölfbrïderstiftung followed the model established by Konrad's grandfather, Konrad Gross, who had founded the famous "Heilig-Geist-Spital" (Hospital of the Holy Spirit) in Nuremberg in 1332 and which was soon co-financed by numerous donations by other people. ${ }^{32}$ Every year 12 retired, old, or sick craftsmen were accepted into the Institution, who had to attend church services in the city and had to pray for the founder, Mendel. The number twelve was a direct reminder of the twelve apostles.

This famous Hausbuch served as a memorial and obituary at the same time and indicated the great respect which the merchant Mendel had for those highly skilled and artistically endowed craftsmen. Each illumination portrayed the entire spectrum relevant for the profession, including not only the image of the individual craftsman, but specifically also his tools, materials, the work process, the characteristic workshop, and the end product. Even though these craftsmen who belonged to the Foundation could no longer work fully and by themselves, the images show them, though always already in their old age, still practicing their art in a specific

\footnotetext{
${ }^{29}$ Barack, "Schlusswort" (see note 9), 447.

${ }^{30}$ See, for example, the Strassburg Cathedral's Book of Donors, as discussed by Stanford, Commemorating the Dead in Late Medieval Strasbourg: The Cathedral's Book of Donors and Its Use (1320-1521). Church, Faith and Culture in the Medieval West (Farnham, Surrey, England, and Burlington, VT: Ashgate, 2011), esp. 28-38.

31 This most valuable manuscript is today kept in the Stadtbibliothek Nürnberg, Amb. $217.2^{\circ}$; see the excellent webpage http://www.nuernberger-hausbuecher.de/index.php?do=page\&mo=2 (last accessed on Jan. 17, 2015); see also the print edition Hausbuch der Mendelschen Zwölfbrüderstiftung zu Nürnberg: Deutsche Handwerkerbilder des 15. und 16. Jahrhunderts, ed. Wilhelm Treue. 2 vols. (Munich: Bruckmann, 1965); for a useful introduction to the whole topic, see Wolfgang Metzger, Handel und Handwerk des Mittelalters im Spiegel der Buchmalerei (Graz: Akademische Druck- und Verlagsanstalt, 2002).This book is now also pleasantly presented in Die Nürnberger Hausbücher: Die schönsten Handwerkerbilder aus dem Mittlelalter, ed. Christine Sauer and Elisabeth Sträter (Darmstadt: Primus Verlag, 2012).

32 Annamaria Böckel, Heilig-Geist in Nürnberg. Spitalstiftung \& Aufbewahrungsort der Reichskleinodien. Nürnberger Schriften; 4 (Nuremberg: Böckel, 1990); Ulrich Knefelkamp, Das Heilig-Geist-Spital in Nürnberg vom 14-17. Jahrhundert. Geschichte, Struktur, Alltag (Nuremberg: Selbstverlag des Vereins für Geschichte der Stadt Nürnberg, 1989); see also http://www.franken-wiki.de/index.php/Heilig-Geist-Spital.
} 
fashion. In the early years the images are accompanied just by names and life dates; in the subsequent period that information was considerably expanded to include whole biographies.

The Mendel institution and its memorial book were complemented in 1511 by the mine owner Matthäus Landauer, who created a similar retirement community, the "Landauersche Zwölfbrüderstiftung" and who had just the same kind of memorial book created (from now on: Landauer Hausbuch). ${ }^{33}$ This one contains 439 pages with 406 portraits of craftsmen. Both works were maintained and continued until 1806. In 1777, the famous Nuremberg scholar Christoph Gottlieb von Murr ${ }^{34}$ provided the following commentary about a later section in this memorial book, for which Marquart Mendel had been responsible during his time in office (1425-1438):

Es ist zu wissen das in diesem puch gemolt sten alle die pruder die in dem almusen der zwelf pruder gestorben sind vnd was hantwerk sy gewesen sind vnd vnter was pfleger sy tod sind vnd wenn yeder pfleger an getreten ist vnd auch wen er gestorben ist. Vnd das puch hat Marquart Mendel pfleger der zwelf pruder zu samen pracht vnd lassen machen. Vnd hat das genomen auß seins anherrn Conrad Mendels stifter alten puchern etc. ${ }^{35}$

[Know that all the brothers who have died in this Institute of the Twelve Brothers have been portrayed here. Those images show us what craftsmanship they practiced and under whose administrator of the Institute they died and when each administrator began with his duties, and when he died. The administrator of the Institute of the Twelve Brothers, Marquart Mendel, had ordered this book to be put together. He drew much for it from the old books by his forefather Conrad Mendel who had founded the Institute.]

While von Murr categorized this memorial book as a necrology, modern scholarship has preferred the term "Housebook," reflecting more the institutional character, mirroring the actual members of the Institute that wanted to have an accurate, almost photographic reflections of its deceased members and their many different crafts. This kind of institution was copied in numerous other south-German cities, such as in Augsburg, Regensburg, and Ingolstadt.

From 2007 to 2009 both the Mendel and the Landauer memorial books were digitized and hence are now available online. ${ }^{36}$ Whereas Des Teufels Netz pursued specific religious intentions, and in that framework brought the many different professions among the craftsmen to the forefront, this Hausbuch intends virtually only to present the craftsmen in their actual work conditions, showing us through the spectacular drawings the specifics of their trade, their tool, their actions, and the product. Often the same professions are represented because the portraits serve also as individual depictions for the sake of memory. We see, for instance, an image of Heinrich Rettich (d. Feb. 22, 1641; Landauer I, fol. 105v), who worked as an "Altmacher," that is, as a man

\footnotetext{
${ }^{33}$ Joachim Ahlborn, Die Familie Landauer vom Maler zum Montanherren. Nürnberger Forschungen, 11 (Nuremberg: Verein für Geschichte der Stadt Nürnberg, 1969).

${ }^{34}$ Renate Jürgensen, Bibliotheca Norica: Patrizier und Gelehrtenbibliotheken in Nürnberg zwischen Mittelalter und Aufklärung. Beiträge zum Buch- und Bibliothekswesen, 43. 2 vols. (Wiesbaden: Harrassowitz Verlag, 2002), vol. 2, 1310-29. There is, however, no reference to Mendel in this compendious work on von Murr's library. See von Murr's own study, Beschreibung der vornehmsten Merkwürdigkeiten in des H.R. Reichs freyen Stadt Nürnberg und auf der hohen Schule zu Altdorf Nebst einem chronologischen Verzeichnisse der von Deutschen, insonderheit Nürnbergern, erfundenen Künste, vom XIII Jahrhunderte bis auf jetzige Zeiten (Nuremberg: Johann Eberhard Zeh, 1778). Cf. also his critical study, "Versuch einer Nürnbergischen Handwerksgeschichte vom dreyzehnten Jahrhunderte bis zur Mitte des sechzehnten ... aus Originalurkunden," Journal zur Kunstgeschichte und zur allgemeinen Literatur 5 (1777): 37-179. However, I was not able to consult these items personally.

35 http://www.nuernberger-hausbuecher.de/docs/stbn_beschreibung_317.pdf (last accessed on Jan. 17, 2015); see also Heinz Zirnbauer, "Vmb Gots vnd vmb des Hantwercks willen": Von der Mendelschen Zwölfbrüder-Stiftung und von ihrem Hausbuch (Munich: Bayerischer Rundfunk, 1966), 92.

${ }^{36} \mathrm{http}: / / w w w . n u e r n b e r g e r-h a u s b u e c h e r . d e /$ (last accessed on Jan. 19, 2015).
} 
repairing old shoes. The artist presents him, like all the other craftsmen, in his own workshop, with an old shoe placed between his legs, while the work tools are placed in front of him on a tray. Even though he looks out of the picture into the distance, he holds a thread with both hands and is apparently in the process of repairing the shoe.

Even though the late date of 1641 might remove us entirely outside of the Middle Ages in the commonly accepted chronological framework, this Hausbuch undermined all possible historical markers since the tradition of creating these images began already in 1425/1426 and continued until 1806. My intention here cannot be to investigate possible art-historical differences between those portraits from the seventeenth or eighteenth centuries on the one hand with those from the fifteenth century on the other, which might be detectable in small but insignificant details, such as clothing, bodily representation, and facial features, but the overarching style and the mechanics of creating these images apparently stayed the same over the centuries. Most importantly, hence, rather proves to be the detailed representation of the craftsmen at their work place with all the tools at hand and operating in their job, although all of them are depicted as old men.

Fritz Buhler, for instance, who died on April 8, 1521, worked as a carpenter, which we can recognize immediately from the painting, which shows him standing next to a large wooden beam which he cuts into the right shape with the help of a large axe (Amb. 279.2 ${ }^{\circ}$, Landauer I, fol. 12v.). Another carpenter was Michael Begel (d. April 15, 1674), who, while looking at the spectator, uses his tools to prepare a wooden beam for the construction of a house (Amb. 279.2 ${ }^{\circ}$ Folio 143 v., Landauer I). Peter Zymerman (d. before 1423), is depicted in almost the same activity, though the artist, still steeped in late Gothic techniques, presented him more stilted and statuary (mb. $317.2^{\circ}$ Folio $37 \mathrm{r}$. Mendel I). The artists' concerns were simply the same, portraying the craftsman in his typical working position, illustrating as concretely as possible how he carried out his characteristic tasks, operating with his tools and working on wood. Every time we recognize that these are old men, both because of their white hair and a receding hair line. Rudolf Meir (d. August 13, 1454; Amb. 317.2 ${ }^{\circ}$ Folio $76 \mathrm{r}$., Mendel I) is presented within the wooden frame of a future half-timbered house, holding a small axe in his hand, while a larger one is resting on the floor, next to an auger for drilling holes.

Later artists tended to increase the number of tools and also experimented with situating the craftsman in an outdoor setting, such as in the case of Hans Knauerman (1578; Amb. 317b.2 $2^{\circ}$ Folio 37 v., Mendel II). We can even recognize some background, opening up to a mountainous landscape with a city at the foot of the hill, typical of late medieval artistic style. In other words, there are strong stylistic differences reflecting the changing times, but the overall approach and intention, portraying the old craftsman in his characteristic setting, remained the same throughout.

Most fascinating proves to be, just as in the case of Des Teufels Netz, how many different crafts are represented here. We find examples of spur makers (Andreas Sporer, 1457; Amb. 317.2 ${ }^{\circ}$ Folio 78 r., Mendel I), parchment makers (Fritz Pyrmetter, ca. 1425; Amb. 317.2 ${ }^{\circ}$ Folio 34 v., Mendel I); jewellers (Friderich Direr, d. November 3, 1611; Amb. 317b.2 $2^{\circ}$ Folio 110 v., Mendel II); glass makers (Niclas Klucel, d. May 29, 1554; Amb. $279.2^{\circ}$ Folio 40 r., Landauer I); and many others. Without going into further details, there are, for instance, butchers, thimble makers, flutists, coachmen, glass painters, inn-keepers, thread-makers (gold and silver), belt makers, blacksmiths for helmets, and other smiths for a variety of other parts of a knight's armor, hat makers, comb makers, cheese makers, cooks, haberdashers, coopers, line weavers, leather makers, teachers, servants, sacristans, people in charge of weighing flour to guarantee the right price, masons, supervisors of 
mills, nail makers, public notaries, organ makers, organ players, butchers of oxen, priests, mail deliverer (1779), makers of rosaries, brewers, etc.

Apparently, the specific concept of "craftsmen" was soon dissolved since retirees from many different jobs ended up in this old age retirement community within the city. Anyone who had earned his own living working in one or the other fashion was invited to join, whereas the aristocrats, the learned, and the bureaucrats are not included, simply because they had other means available to them to finance their life in retirement. The retired city clerk was as much allowed to enter the Mendel Stiftung as the mercenary, teacher, scribe, cloth maker and cloth merchant, tower guards, and also bird catcher (Paulus, 1481; Amb. 317.2 ${ }^{\circ}$ Folio 99 r., Mendel I). In other words, the Stiftung was open to almost all ordinary citizens of the city, unless they were too wealthy and belonged to the class of rich merchants (patricians), city councilors, higher ranked clergy, or aristocrats.

Research on this institution in Nuremberg dates back well into the early twentieth century, ${ }^{37}$ if not even to the eighteenth century, if we keep the work of Christoph Gottlieb von Murr in mind (see above). This great interest is fully justified because the informational value concerning the lives of late medieval craftsmen in this imperial city, Nuremberg, is most extraordinary. Not only do we learn much about the actual working conditions of craftsmen, we also encounter a huge number of historically datable and identifiable craftsmen.

These most important book illuminations add much to our knowledge about tools used by craftsmen, their work clothing, and their work spaces. Even though the Hausbuch portrays only old and retired craftsmen and others, we can trust the artists' presentations as realistic and detailed. Since they are commonly situated in specific and almost identifiable spaces, while still working in their old age, it is most likely that they are shown here in their workshops in the Mendelsche Stiftung. ${ }^{38}$

This collection was of course not the only one available from the Middle Ages; on the contrary, many illuminated medieval manuscripts depict scenes from the world of craftsmen, especially because Joseph, husband of the Virgin Mary, was known to have been a carpenter, such as in the Mérode Altarpiece, a triptych by the Early Netherlandish painter Robert Campin from ca. $1425-1428 .{ }^{39}$ He gained his status as a saint only since the early seventeenth century, but many medieval manuscripts still contained images of him working in the background..$^{40}$ Nevertheless, the Mendelsche Hausbuch represented an extraordinarily rich masterpiece in book production because it was an obituary, memorial, and a reference work for the vast range of crafts as practiced in the late Middle Ages. In light of these observations, we can now proceed to our conclusion and end with a comparison between this vast opus of obituary images and Des Teufels Netz.

\footnotetext{
${ }^{37}$ Friedrich Bock, Deutsches Handwerk im Spätmittelalter: Bilder aus dem Hausbuch der Mendelschen Zwölfbrüderstiftung in Nürnberg (Leipzig: Insel-Verlag, 1935); Karl Fischer, Hausbuch der Mendelschen Zwölf-Brüderstiftung in Nürnberg. Vols. 1-3:,

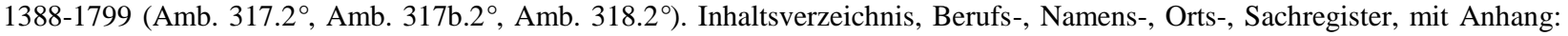
Berufs-Register zu den Landauer-Brüderbüchern, Stadtbibliothek Nürnberg, Vol. 1: (Amb. 279.2 ${ }^{\circ}$; Vol. 2: (Amb. 279b.2 ${ }^{\circ}$ ) (Stadtbibliothek Nürnberg, Amb. 1120.4) (Nuremberg: Stadtbibliothek, 1953); Margarete Wagner, Nürnberger Handwerker: Bilder und Aufzeichnungen aus den Zwölfbrüderhäusern, 1388-1807 (Wiesbaden: Pressler, 1978); Walter Eckehart Spengler, "Bildquellen zur Handwerksgeschichte: Die Nürnberger Zwölfbrüderbücher," Rheinisches Jahrbuch für Volkskunde 32 (1997): 189-201; Gerhard Fouquet, "Zwölf-Brüder-Häuser und die Vorstellung vom verdienten Ruhestand im Spätmittelalter," Sozialgeschichte mittelalterlicher Hospitäler, ed. Neithard Bulst and Karl-Heinz Spieß. Vorträge und Forschungen, 65 (Ostfildern: Thorbecke, 2007), 37-76.

${ }^{38}$ Metzger, Handel und Handwerk (see note 31), 144, et passim.

${ }^{39} \mathrm{http}: / /$ en.wikipedia.org/wiki/M\%C3\%A9rode_Altarpiece (last accessed on Jan. 19, 2015).

40 Esther Meier, Handbuch der Heiligen (Darmstadt: Wissenschaftliche Buchgesellschaft, 2010), 324-26. See also http://en.wikipedia.org/wiki/Saint_Joseph (last accessed on Jan. 19, 2015).
} 
The former was a long-term project to memorialize the inhabitants of the Mendel Foundation as worthy and highly recognized craftsmen. This Hausbuch reflects a strong pride in late medieval craftsmanship and other professions. Eventually the institution accepted virtually everyone who was worthy and belonged to the urban community or had originated from outside, including the peasant Cuntz Holfelder (1521; Amb. 279.2 ${ }^{\circ}$ Folio 12 r., Landauer I) or the soldier Wilhelm Wager (1697; Amb. 317b.2 ${ }^{\circ}$ Folio 201 r., Mendel II). Nevertheless, the focus strongly rested on the craftsmen, who made up the vast majority of the Foundation's membership. The pictorial material provides an enormous breadth of information about tools, types of profession, products, and clothing used during the work. At times we are also informed about sicknesses, moral shortcomings, and character peculiarities. But there is very little effort to inject judgments and personal comments.

In contrast, Des Teufels Netz was the result of the poet's strong criticism of countless failures and shortcomings in his society. Through the discussion between the devil and the hermit representatives of virtually every social class are highlighted and exposed in their sinfulness and moral failures. In that process the anonymous poet utilized the opportunity to cover also the wide range of craftsmen and thus created an intriguing portrait of the social conditions in late medieval cities. Even though his interest was centered on identifying how the individual craftsmen, among others, abused their positions to increase their profit or how they worked in their profession resorting to evil practices or employing bad or poor material, this didactic-moral verse narrative still contains a vast treasure trove of concrete information about the world of craftsmanship.

The poet demonstrates an astonishing degree of expertise about the many different professions and is obviously aware about the many common complaints raised by the consumers and customers. If we read Des Teufels Netz in that light, we can place it right next to the Mendel Hausbücher and the Landauer Hausbücher, although there we are presented with mostly visual portraits of the plethora of craftsmen and their crafts. While the latter text mirrors the historical development of the crafts throughout the centuries, Des Teufels Netz was created around the time of the Council of Constance or the Council of Basel, that is, in the first third of the fifteenth century.

Both works complement each other remarkably and deserve great respect for the huge amount of data which they make available. There are tendencies to project an ideal world free of sinfulness, and when Christ Himself at the end speaks up, angry about people's ignorance and failings (13521ff.), we recognize parallels to the genre of the late medieval Judgment plays since the host of souls is divided between the good, who are allowed to enter heaven, and the evil, who are condemned to hell (13604ff.). Nevertheless, the specific criticism of each individual social group or class and the concrete discussion of how they commit their characteristic sins make it possible to draw much important information about the many types of craftsmanship and other professions, including shepherding, farming, running inns, and prostitution. ${ }^{41}$

We might even consider drawing some parallels to the famous humanist collection of satirical poems by Sebastian Brant in his Narrenschiff (1494), ${ }^{42}$ although there the poet pursues quite different perspectives and is not at all driven by religious motives. Brant ridicules people and their behavior, addressing a multitude of

\footnotetext{
${ }^{41}$ Hofer, "Wenn der Teufel an den Sündern leidet" (see note 13), 24.

${ }^{42}$ Sebastian Brant, Das Narrenschiff: Nach der Erstausgabe (Basel 1494) mit den Zusätzen der Ausgaben von 1495 und 1499 sowie den Holzschnitten der deutschen Originalausgabe, ed. Manfred Lemmer. Third expanded ed. (1962; Tübingen: Max Niemeyer, 1986).
} 
human shortcomings in all of its foolishness, but he also ridicules ordinary activities and behavior, proving thus his profoundly satirical attitude so characteristic of early modern humanism. ${ }^{43}$ But we would look in vain for specific discussions of craftsmanship, of individual professions, or of social classes. Instead, Brant reflects upon useless books, children's behavior, gluttony, excessive worrying, foolish wishfulness, wrongful blaming of God, contemptible righteousness, bad behavior in church during mass, poor parenting, lustfulness, dancing, usury, and many other aspects of a great diversity.

By contrast, if we want to learn more about what fifteenth-century and later authors and artists had to say about craftsmanship, we are in the fortunate situation of having both Des Teufels Netz and the Mendel Hausbuch available as most valuable sources, giving us both a wealth of concrete information and revealing the perspectives pursued by conservative critics regarding people's wrongdoing and criminal behavior in their professions. While the anonymous poet of the former text is most vocal in his criticism and dramatically targets individual professions or representatives of the various social classes, the textual comments in the latter text are more subtle and yet also reveal personal character flaws and moral or behavioral weaknesses, such as alcoholism, depression, dementia, or lunacy. Sometimes those are mentioned as the cause of the death, and sometimes as a failure of the individual character.

Rarely do we come across late medieval documents that allow us to cast an eye into the social reality as drastically as in both of these discussed above. There are strong differences between both, as we have noted, but both still address intensively and directly the world of craftsmanship and bring it to life more than many other documents. ${ }^{44}$ The rich collection of images in the Mendel Hausbuch and the Landauer Hausbuch has been recognized for a long time by German scholarship as most impressive in its artistic and historical value, but Des Teufels Netz has lingered for far too long in the dust of library shelves. In light of the overarching theme of late medieval craftsmanship we need to consult this admittedly very conservative text in close conjunction with the two richly illustrated obituaries produced in Nuremberg, and we can be certain that we will be definitely rewarded for consulting this intriguing literary source for information on the social structure, the range of professions, marginal figures, and also gender relations and the evaluation of both the aristocracy and the clergy.

From here we could move on to the artistic work of Christoph Weigel d. Ä. who presented in a large number of engravings images of all kinds of professions and social ranks in his Ständebuch from 1698 created upon personal visits to the many different workshops and in close consultation with the individual craftsmen. ${ }^{45}$ It would be most fascinating to investigate, for instance, whether he drew inspiration from the Mendel or the Landauer Housebook, since he had settled in Nuremberg in the same year, ${ }^{46}$ but this would take us far beyond our time frame for the present study. Nevertheless, it deserves to be noted as a conclusion that the late Middle Ages experienced the full "discovery" of the craftsmen as significant artistic motifs and as most important members of urban society who deserved a thorough treatment in didactic and religious writings.

\footnotetext{
${ }^{43}$ Barbara Könneker, Satire im 16. Jahrhundert: Epoche-Werke-Wirkung. Arbeitsbücher zur Literaturgeschichte (Munich: Verlag C. H. Beck, 1991), 54-68.

${ }^{44}$ Metzger, Handel und Handwerk (see note 31), 54, correctly speaks of the "suggestive Anschaulichkeit der Bilder" (suggestive visuality of the images).

45 http://de.wikipedia.org/wiki/Christoph_Weigel_der_\%C3\%84ltere; for the images, see online http://commons.wikimedia.org/wiki/Category:St\%C3\%A4ndebuch_(Christoph_Weigel_d._\%C3\%84.)?uselang=de (both last accessed on Jan. 19, 2015).

${ }^{46}$ Michael Bauer, "Christoph Weigel (1654-1725), Kupferstecher und Kunsthändler in Augsburg und Nürnberg," Archiv für Geschichte des Buchwesens 23 (1983): 693-1186.
} 


\section{References}

Nicola, C. (1991). Masons and sculptors. Medieval Craftsmen. London: British Museum Press.

Elizabeth, E. (1992). English tilers. Medieval Craftsmen. London: British Museum Press.

Blair, J., \& Ramsay, N. (Ed.). (1991). English medieval industries: Craftsmen, techniques, products. London and Rio Grande, OH: Hambledon Press.

Hans, H. (1967). Künstler und Werkstatt der Spätgotik. 2nd ed. Darmstadt: Wissenschaftliche Buchgesellschaft.

Cherry, J. (2011). Medieval goldsmiths. Medieval Craftsmen. 2nd ed. London: British Museum Press.

Metzer, W. (2002). Handel und Handwerk des Mittelalters im Spiegel der Buchmalerei. Graz, Austria: Akademische Druck- und Verlagsanstalt.

Morony, M. G. (2003). Manufacturing and labour. Aldershot, Hant, England, and Burlington, VT: Ashgate.

Ovitt, G. (1987). The restoration of perfection: Labor and technology in medieval culture. New Brunswick: Rutgers University Press.

Pfaffenbichler, M. (1992). Armourers. Medieval Craftsmen. London: British Museum Press.

Sauer, C. (2012). Handwerk im Mittelalter. Darmstadt Primus-Verlag.

Spätmittelalter am Oberrhein: Alltag, Handwerk und Handel 1350-1525. Große Landessausstellung Baden-Württemberg, 29. September 2001-3. Februar 2002: Maler und Werkstätten: 1450-1525, ed. Sönke Lorenz, Marcus Dekiert, and Dietmar Lüdke. 2 vols. Spätmittelalter am Oberrhein, 1. Stuttgart: Thorbecke. 2001.

Stadt und Handwerk in Mittelalter und früher Neuzeit, ed. Karl Heinrich Kaufholdand Wilfried Reininghaus. Städteforschung, Reihe A, 54. Cologne: Böhlau, 2000.

Swanson, H. (1983). Building craftsmen in late medieval York. York: University of York. 